\title{
Pelaksanaan Opiumpacht: Monopoli Perdagangan Opium Melalui Perantara Bandar di Keresidenan Kediri, 1833-1900
}

\author{
AHMAD FATHONI; SARKAWI B. HUSAIN \\ Departemen Ilmu Sejarah, Universitas Airlangga \\ Corresponding Author: fathonia41@gmail.com
}

\begin{abstract}
The opium trade in Kediri Residency was monopolized by Dutch East Indies government. The problem discussed in this study regarding opium trade monopoly at Kediri Residency through bookie intermediary (opiumpachter) in 1833-1900. The methods used in this research is historical methods which includes heuristics, criticism, interpretation and historiography. The result showed that the opium trade monopoly through bookie intermediary (opiumpachter) in Kediri Residency included auction and distribution processions also the sale of raw opium to opium dealers. Generally, the opium trade in Kediri Residency was controlled by Chinese. They become intermediary traders who sell government opium to people in Kediri Residency. The high tax offer at opium auction in Kediri Residency gave high profits to the country. On the contrary, that puts a great deal of pressure on the opium port. The crisis which occurred at the end of the 19th century, caused a setback in the opium trade monopoly through bookie intermediary (opiumpachter) in Kediri Residency.
\end{abstract}

\begin{abstract}
Abstrak
Perdagangan opium di Keresidenan Kediri dimonopoli oleh pemerintah Hindia Belanda. Permasalahan yang dibahas dalam penelitian ini mengenai monopoli perdagangan opium di Keresidenan Kediri melalui perantara Bandar (opiumpachter) pada tahun 1833-1900. Metode yang digunakan dalam penelitian ini adalah metode sejarah yang meliputi heuristik, kritik, interpretasi dan historiografi. Hasil penelitian menunjukkan bahwa monopoli perdagangan opium melalui perantara Bandar (opiumpachter) di Keresidenan Kediri meliputi prosesi lelang dan distribusi serta penjualan opium mentah kepada bandar opium. Pada umumnya perdagangan opium di Keresidenan Kediri dikuasai oleh orang-orang Tionghoa. Mereka menjadi pedagang perantara yang menjual opium pemerintah kepada masyarakat di Karesidenan Kediri. Tingginya tawaran pajak pada lelang opium di Keresidenan Kediri memberikan keuntungan yang tinggi pada negara. Sebaliknya, hal tersebut membuat tekanan yang besar pada bandar opium. Krisis yang terjadi pada akhir abad ke-19 menyebabkan kemunduran dalam monopoli perdagangan opium melalui perantara Bandar (opiumpachter) di Keresidenan Kediri.
\end{abstract}

Keywords:

Kediri

Residency; monopoly; opium trade; opiumpachter

Kata kunci: Keresidenan Kediri; monopoli; perantara bandar; perdagangan opium 


\section{Pendahuluan}

Penyalahgunaan zat psikoaktif telah menjadi masalah umum yang bersifat universal (Adnil Edwin Nurdin, 2007: 8). Salah satu di antaranya adalah opium. Opium menjadi salah satu jenis narkotika golongan tingkat pertama yang peredarannya dilarang keras oleh negara. Jika dilihat dari sudut pandang historis bangsa Indonesia, mengkonsumsi opium telah ada jauh sebelum kedatangan orang-orang Barat di Jawa. Orang-orang Jawa menggunakan opium sebagai bahan utama dalam pembuatan madat. Kebiasaan orang-orang Jawa dalam menghisap madat telah tercantum dalam sebuah larangan molimo yang terdiri dari madat atau mengkonsumsi opium, madon atau melacur, maling atau mencuri, mabuk atau minum-minuman keras dan main atau berjudi (Adnil Edwin Nurdin, 2007: 23).

Pada awalnya opium dikenal sebagai obat penghilang rasa nyeri yang ampuh. Namun, apabila digunakan secara berlebihan opium memiliki efek ketergantungan dan bisa berujung kematian pada setiap pemakai atau pengguna opium. Sifat ketergantungan dari pengguna opium inilah yang menjadikan penjualan opium sangat disukai dalam dunia perdagangan. Perdagangan opium selalu dianggap sebagai salah satu usaha yang memberikan keuntungan besar. Hal tersebut didasari oleh sifat dari kandungan dalam opium yang memudahkan pedagang untuk mencari pangsa pasar. Oleh karena itu, pada perkembangannya perdagangan opium menjadi salah satu bagian penting dalam proses penjajahan yang dilakukan oleh pemerintah Hindia Belanda di Jawa.

Belum diketahui secara pasti tepatnya kapan dan dibawa oleh siapa masuknya opium di Jawa. Sejak kedatangan Belanda ke Jawa pada akhir abad ke-16, opium sudah menjadi suatu komoditas yang sangat penting dalam dunia perdagangan lokal (Julianto Ibrahim, 2013: 67). VOC melakukan perjanjian dengan Raja Amangkurat II pada tahun 1677 untuk memasukkan opium ke wilayah Kerajaan Mataram (James R. Rush, 2012: 27). Sejak saat itu, kegiatan perdagangan opium di Jawa telah dimonopoli oleh VOC. Aktivitas perdagangan opium selain yang dilakukan oleh VOC di Jawa, dianggap sebagai tindakan penyelewengan (ilegal) oleh pihak Kerajaan Mataram. Kegiatan tersebut berlanjut pasca VOC digantikan oleh pemerintahan Hindia Belanda. Secara bertahap mereka melakukan monopoli perdagangan opium dengan pelaksanaan opiumpacht di seluruh wilayah bagian dari kekuasaan pemerintah Hindia Belanda.

Wilayah Keresidenan Kediri sebelum tahun 1830-an termasuk salah satu bagian dari kekuasaan Kerajaan Mataram Islam dengan sebutan Mancanegara Wetan atau Mancanegara Timur (Sartono Kartodirdjo, Marwati Djoened Poesponegoro, dkk, 1977: 2). Akibat dari Perang Jawa yang terjadi pada tahun 1825-1830, pemerintah Hindia Belanda menganeksasi wilayah Keresidenan Kediri. Sejak saat itu, Keresidenan Kediri menjadi bagian dari 
koloni pemerintah Hindia Belanda. Keresidenan Kediri dijadikan salah satu wilayah dengan pelaksanaan opiumpacht di bawah kontrol pemerintah Hindia Belanda.

Artikel ini bertujuan untuk menjelaskan mengenai monopoli pemerintah Hindia Belanda dalam perdagangan opium di Keresidenan Kediri tahun 1834-1900.

Pelaksanaan opiumpacht dibagi menjadi dua tahap mulai dari prosesi lelang, distribusi dan penjualan opium mentah kepada bandar. Kemunduran pelaksanaan opiumpacht ditandai dengan adanya krisis yang terjadi pada akhir abad ke-19. Para bandar opium mengalami kesulitan dalam pembayaran pajak sehingga banyak di antara bandar bangkrut dengan menderita hutang-hutang yang tinggi kepada negara.

\section{Pelaksanaan Opiumpacht, 1833-1900}

Secara resmi wilayah Keresidenan Kediri sejak tahun 1830-an dianeksasi oleh pemerintah Hindia Belanda. Setelah tahun tersebut, Keresidenan Kediri dijadikan salah satu wilayah pemasaran dari perdagangan opium yang dilaksanakan oleh pemerintah Hindia Belanda. Keresidenan Kediri mulai tahun 1833 mendapatkan pasokan opium mentah dari gudang negara yang ada di Surabaya (J.C. Baud and Hoffman, 1853: 162). Proses penyediaan opium mentah ditentukan melalui sistem lelang. Pada sistem lelang ditentukan jumlah toko penjualan dan jumlah opium mentah yang bisa disediakan oleh negara serta tingginya pajak opium yang bisa dibayarkan oleh opiumpachter.

Setelah proses lelang telah berhasil menentukan besaran pajak, jumlah toko dan opium mentah yang disediakan maka proses selanjutnya yaitu mendistribusikan opium mentah kepada para bandar opium yang terpilih dalam sistem lelang. Proses distribusi dalam pelaksanaan opiumpacht dilakukan dengan dua tahapan yakni pertama melalui distribusi minimum dengan ketentuan tiban (jumlah minimum yang disediakan pemerintah) dan siram (jumlah tambahan atas permintaan bandar opium). Kedua melalui sistem distribusi maksimum. Pada pelaksanaan distribusi minimum dilakukan pada fase awal pelaksanaan opiumpacht dari tahun 1833 hingga tahun 1861. Pada fase kedua yakni pada tahun 1870-1872. Pada pelaksanaan distribusi maksimum dilakukan pada fase pertama yakni tahun 1862-1869. Pada fase kedua yakni pada tahun 1873-1900 di Keresidenan Kediri.

\section{Prosesi Lelang}

Pelaksanaan opiumpacht adalah sistem monopoli perdagangan opium dengan cara memborongkan penjualan opium eceran kepada bandar. Sistem pemborongan penjualan opium secara eceran ditentukan melalui lelang opium di Keresidenan Kediri. Mereka yang memenangkan lelang 
memperoleh hak secara eksklusif untuk menguasai penjualan opium eceran kepada konsumen (James R.Rush, 2012: 1).

Prosesi lelang opium telah dilakukan sebelum pemerintah Hindia Belanda berkuasa di wilayah Keresidenan Kediri. Namun, secara formal baru ditetapkan oleh Daendels pada tahun 1809 di bawah kontrol penuh dari pemerintah Hindia Belanda (Abdul Wahid, 2013: 67). Pada waktu itu, prosesi lelang opium telah melibatkan peran media khususnya surat kabar dalam proses publikasi secara resmi. Daendels melibatkan Bataviasche Koloniaal Courant yang secara resmi untuk menyebarkan atau mengumumkan diadakannya sebuah lelang opium. Prosesi lelang hanya dilakukan untuk beberapa wilayah tempat penjualan opium eceran seperti Batavia, Semarang dan Surabaya.

Seiring dengan semakin luasnya kekuasaan pemerintah Hindia Belanda, kegiatan monopoli perdagangan opium juga semakin diperluas. Proses pengumuman lelang opium juga telah melibatkan beberapa Surat kabar yang sedang mengalami perkembangan. Pada saat itu, ada beberapa Surat kabar yang menjadi mitra pemerintah seperti Javaasche Courant, Batavia Handelsblad di Batavia, dan Soerabaiasch Handelsblad serta De Locomotief: Handelsen Advertientie Blad (Abdul Wahid, 2013: 75).

Pelaksanaan lelang opium sebelum tahun 1867 menjadi tanggungjawab dari direktur sumber daya dan daerah. Pelaksanaan lelang setelah tahun tersebut menjadi tanggungjawab dari direktur keuangan. Proses pelaksanaan lelang selalu dilakukan dengan persiapan yang matang. Hal tersebut ditunjukkan dengan sebuah pengumuman lelang yang dilakukan pada jauhjauh hari dengan perkiraan satu sampai dua bulan sebelum masa berakhirnya opiumpacht. Selain itu, pemerintah selalu melibatkan peran media yakni Surat kabar dalam proses publikasi resmi lelang opium.

Berdasarkan Staatsblad van Nederlandsche Indie no 206 tahun 1881, pemerintah membagi pacht dalam pendapatan pajak kecil (kleine verpachte middelen) terhadap penjualan opium eceran tahun 1880 (Abdul Wahid, 2013: 81). Peraturan tersebut dilakukan untuk memudahkan pengawasan yang dilakukan pemerintah sehingga penyelewengan-penyelewengan bisa diminimalisir. Sejak saat itu pengumuman lelang opium juga dilakukan secara terpisah pada masing-masing keresidenan. Pelaksanaan jadwal lelang yang sebelumnya menjadi tanggungjawab dari direktur keuangan diserahkan sepenuhnya kepada seorang residen. Salah satu contoh berdasarkan publikasi Surat kabar yang secara langsung ditandatangai oleh Residen Kediri tentang diadakannya sebuah lelang opium untuk memperebutkan hak penjualan opium eceran di Keresidenan Kediri dari tahun 1887 hingga 1889. Pelaksanaan lelang dilakukan pada hari sabtu, tanggal 30 Oktober 1886 pukul 9 pagi di kediaman Bupati Kediri (Soerabaiasch-Handelsblad, 1886).

Prosesi lelang secara lebih lengkap bisa dilihat melalui peraturan 
opiumpacht pada tahun 1898 berdasarkan Staatsblad van Nederlandsch-Indie no. 256 tahun 1898 yang mengatur jalannya lelang opium untuk memperoleh penjualan eceran tahun 1899-1900 di Keresidenan Kediri. Pasal 1, Hak penjualan opium di Keresidenan Kediri dipachtkan selama 2 tahun yakni tahun 1899 dan 1900. Pasal 2, Pelaksanaan opiumpacht dilakukan melalui sistem lelang yang diadakan dalam satu tempat di Kediaman Bupati Kediri. Pasal 3, Pelaksanaan lelang dipimpin langsung oleh Residen Kediri. Pasal 4, penawaran umum pada pelaksanaan lelang berlangsung berurutan dalam dua bagian yaitu untuk tahun 1899 dan untuk tahun 1900. Pasal 5, Jumlah maksimum opium yang dapat diterima oleh setiap opiumpachter adalah 1.350 kati per bulan. Pasal 6, terdapat 120 Tempat penjualan yang diizinkan untuk opiumpachter di Keresidenan Kediri. Pasal 7, Pemenang lelang diperbolehkan menentukan proporsi jumlah yang diinginkan dalam setiap bulan pada jenis Opium Levant atau Bengal dari jumlah opium mentah yang dapat diterima berdasarkan ketentuan maksimum. Pasal 8, opiumpachter menerima pasokan opium mentah dari gudang negara yang ada di Surabaya. Pasal 9, Pembayaran jumlah opium dilakukan setiap bulan atau pada hari terakhir bulan sebelum pembayaran, apabila telah melewati tempo yang ditetapkan bisa dikenakan denda sebesar $f 30$. Pasal 10, peraturan ini berlaku mulai pada hari pengumuman pacht dan disebarkan dalam bahasa pribumi dan bahasa Tionghoa (Staatsblad van Nederlandsch-Indie no. 256 tahun 1898).

Berdasarkan tabel 1 mengenai tawaran lelang opiumpacht yang diperoleh di beberapa keresidenan yang ada di Jawa menunjukkan bahwa wilayah Keresidenan Kediri selalu unggul dibandingkan dengan keresidenan lain. Pelaksanaan lelang opium pemerintah di wilayah Keresidenan Kediri menjadi salah satu yang paling tinggi. Tawaran yang dihasilkan Keresidenan Kediri pada tahun 1870 sebesar $f 600.000$. Pada hasil tawaran lelang opium tahun 1871-1872 turun drastis hanya mencapai $f 48.000$ dalam setahun. Namun, wilayah Keresidenan Kediri kembali memperoleh tawaran yang tinggi pada tahun 1873-1900. Pajak perdagangan opium mulai tahun 1878 di wilayah Keresidenan Kediri melambung tinggi dengan berhasil memperoleh hingga tiga kali lipat dari kondisi tahun-tahun sebelumnya. Kondisi yang demikian tentu sangat menguntungkan pemerintah sehingga perdagangan opium merupakan salah satu aset yang berharga dalam pemasukan kas negara. Sebagian besar pendapatan pemerintah kolonial berasal dari perdagangan opium. Mereka dapat melunasi utang-utang negara dan dapat membangun kembali perekonomian Negara Belanda sebagai induk dari tanah jajahan.

Pelaksanaan lelang opium pada tahun 1873 tawaran yang diperoleh pemerintah mengenai pajak opium terus meningkat. Adanya peningkatan yang terjadi merupakan salah satu keberhasilan pemerintah dan menjadi tahun keemasan dari pelaksanaan perdagangan opium eceran di Keresidenan Kediri. Pada waktu itu, pemerintah menetapkan penyediaan maksimum 
Tabel 1. Hasil lelang opium (opiumpacht) dalam beberapa Keresidenan di Jawa tahun 1870-1900

\begin{tabular}{|c|c|c|c|c|}
\hline Tahun & Kediri & Semarang & Surakarta & Surabaya \\
\hline 1870 & $f 600.000$ & $f 320.000$ & $f 540.000$ & $f 384.700$ \\
\hline 1871 & $f 471.600$ & $f 420.000$ & $f 140.520$ & $f 211.200$ \\
\hline 1872 & $f 32.400$ & $f 48.000$ & $f 121.320$ & $f 30.000$ \\
\hline 1873 & $f 792.000$ & $f 660.000$ & $f 558.000$ & $f 456.000$ \\
\hline 1874 & $f 841.200$ & $f 780.000$ & $f 828.240$ & $f 655.200$ \\
\hline 1875 & $f 1.242 .000$ & $f 1.259 .400$ & $f 983.400$ & $f 792.000$ \\
\hline 1876 & $f 1.242 .000$ & $f 1.259 .400$ & $f 983.400$ & $f 792.000$ \\
\hline 1877 & $f 1.242 .000$ & $f 1.259 .400$ & $f 983.400$ & $f 792.000$ \\
\hline 1878 & $f 1.596 .000$ & $f 1.212 .000$ & $f 960.000$ & $f 949.200$ \\
\hline 1879 & $f 1.596 .000$ & $f 1.212 .000$ & $f 960.000$ & $f 949.200$ \\
\hline 1880 & $f 1.596 .000$ & $f 1.212 .000$ & $f 960.000$ & $f 949.200$ \\
\hline 1881 & $f 1.800 .000$ & $f 1.260 .000$ & $f 1.054 .200$ & $f 1.080 .000$ \\
\hline 1882 & $f 1.800 .000$ & $f 1.260 .000$ & $f 1.054 .200$ & $f 1.080 .000$ \\
\hline 1883 & $f 1.800 .000$ & $f 1.260 .000$ & $f 1.054 .200$ & $f 1.080 .000$ \\
\hline 1884 & $f 2.042 .400$ & $f 1.500 .000$ & $f 1.134 .000$ & $f 1.080 .000$ \\
\hline 1885 & $f 2.042 .400$ & $f 1.500 .000$ & $f 1.134 .000$ & $f 1.080 .000$ \\
\hline 1886 & $f 2.042 .400$ & $f 1.500 .000$ & $f 1.134 .000$ & $f 1.080 .000$ \\
\hline 1887 & $f 2.232 .000$ & $f 1.860 .000$ & $f 1.020 .000$ & $f 1.452 .000$ \\
\hline 1888 & $f 2.232 .000$ & $f 1.860 .000$ & $f 1.020 .000$ & $f 1.452 .000$ \\
\hline 1889 & $f 2.232 .000$ & $f 1.860 .000$ & $f 1.020 .000$ & $f 1.452 .000$ \\
\hline 1890 & $f 1.440 .000$ & $f 1.381 .320$ & $f 540.000$ & $f 1.080 .000$ \\
\hline 1891 & $f$ 1.897.200 & $f 1.404 .120$ & $f 744.120$ & $f 1.200 .000$ \\
\hline 1892 & $f 1.956 .720$ & $f 1.476 .120$ & $f 900.720$ & $f 1.308 .000$ \\
\hline 1893 & $f 1.921 .680$ & $f 1.440 .000$ & $f 900.000$ & $f 1.200 .000$ \\
\hline 1894 & $f 1.992 .600$ & $f 1.440 .000$ & $f 1.056 .000$ & $f 1.326 .000$ \\
\hline 1895 & $f 2.115 .720$ & $f 1.440 .000$ & $f 1.056 .000$ & $f 1.326 .000$ \\
\hline 1896 & $f 2.115 .720$ & $f 1.440 .000$ & $f 1.056 .000$ & $f 1.326 .000$ \\
\hline 1897 & $f 2.115 .720$ & $f 1.440 .000$ & $f 1.056 .000$ & $f 1.326 .000$ \\
\hline 1898 & $f 1.896 .720$ & $f 1.500 .000$ & $f 1.128 .120$ & $f 1.140 .000$ \\
\hline 1899 & $f 1.764 .600$ & $f 1.500 .000$ & $f 1.128 .120$ & - \\
\hline 1900 & $f 1.764 .600$ & $f 1.500 .000$ & $f 1.128 .120$ & - \\
\hline
\end{tabular}

Sumber: Pada tahun 1899-1900, wilayah Keresidenan Surabaya sudah diganti pada sistem opiumregie. Diolah dari Statistiek Betreffende de opiumpacht op Java en Madura over de jaren 1870- 1901 dalam Kolonial Verslag 18711901.

sehingga membuat calon-calon bandar opium tergoda dengan melakukan tawaran yang tinggi dalam lelang opium. Bagi opiumpachter yang terpilih, pasokan opium mentah yang ditetapkan semakin tinggi maka semakin besar pula keuntungan yang didapatkan oleh para bandar (pachter). Mereka tidak terlalu khawatir terhadap tawaran tinggi sebab pemerintah memudahkan dengan metode pembayaran yang bisa dilakukan setiap satu bulan sekali. Selain itu, mereka diperbolehkan untuk melakukan kerjasama dalam bentuk kongsi dengan para penawar lain dalam prosesi lelang opium (J.L. Vleming 
Jr, 1989: 59). Oleh sebab itu, dapat diketahui alasan yang logis mengenai tingginya tawaran yang dilakukan oleh calon-calon opiumpachter di wilayah Keresidenan Kediri.

Adanya sebuah kongsi merupakan salah satu elemen yang paling penting dalam persaingan menghadapi lelang. Kongsi mempermudah pengelolaan keuangan para bandar. Pada umumnya mereka terdiri dari beberapa anggota keluarga kaya yang berasal dari daerah yang sama. Pemerintah memperbolehkan di antara anggota kongsi untuk terlibat langsung dalam sebuah pengelolaan perdagangan opium dalam satu keresidenan atau lebih. Pada satu keresidenan, maksimal anggota kongsi yang terlibat berjumlah tiga orang termasuk calon opiumpachter, dua lainnya berperan sebagai penjamin. Mereka bersama-sama saling mengikatkan diri dan menandatangani kontrak dalam sebuah lelang opium (James R.Rush, 2012: 48).

Salah satu yang paling terkenal di Jawa yakni Kongsi Kediri. Kongsi Kediri terdiri dari beberapa anggota Tionghoa kaya yang berasal dari wilayah Kediri. Pemimpin kongsi Kediri bernama Han Liong Ing, seorang Letnan Tionghoa bertempat tinggal di wilayah Berbek, Kertosono (Claudine Lombard-Salmon, 1991: 77-79). Beberapa anggota seperti Tan Boen In, Tan Kok Tong, Tan Soe Lien dan lain sebagainya. Mereka adalah kelompok Tionghoa cabang atas yang memiliki berbagai usaha lain seperti pada perdagangan gula, kopi serta memiliki berbagai perumahan yang ada di Keresidenan Kediri dan sekitarnya (James R.Rush, 2012: 191).

Tabel 2. Beberapa Daftar Nama Bandar Opium di Keresidenan Kediri tahun 1871-1900

\begin{tabular}{cc}
\hline Nama Bandar & Tahun \\
\hline Tan Kok Tong & $1871,1881-1883,1887-1889$ \\
Kwee Siwe Toan & $1873-1874$ \\
Tan Tong Haij & $1875-1877,1884-1886$ \\
Tan Hwat Hien & $1890-1891$ \\
Han Boen Kiet & $1892-1894$ \\
Djie Thay Hien & $1895-1900$ \\
\hline
\end{tabular}

Sumber: Diolah dari De Locomotief: Handels-en advertientie blad, 10 Agustus 1875; James R. Rush, 2012: 54, 66, 191-192. Arsip Nasional Republik Indonesia, Rapport van 11 November 1890 (Koleksi ANRI: Algemene Secretary Serie Grote Bundel Missive Gouvernements Secretary 1890-1942, 1890) no. 3746; Arsip Nasional Republik Indonesia, Rappoort van 10 November 1894 (Koleksi ANRI: Algemene Secretary Serie Grote Bundel Missive Gouvernements Secretary 1890-1942, 1890) no. 3926.

Berdasarkan Tabel 2 sebagian besar perdagangan opium di Keresidenan Kediri selalu dikuasai oleh orang-orang Tionghoa. Banyaknya strategi dan keunggulan dari segi keuangan yang dimiliki oleh orang-orang Tionghoa menjadikan mereka bisa selalu memenangkan lelang opium. Seperti yang telah diketahui, mereka membentuk semacam perkumpulan usaha dari berbagai (kongsi) sehingga memudahkan mereka dalam setiap usaha yang 
digelutinya. Salah satu contohnya mengenai penguasaan perdagangan opium eceran dengan menjadi mitra pemerintah Hindia Belanda.

Nama-nama pemenang lelang opium di Keresidenan Kediri berasal dari orang-orang Tionghoa lokal maupun daerah lain. Nama-nama lokal seperti Kwee Swie Toan, Tan Kok Tong dan Tan Hwat Hien (anak Tan Kok Tong), Tan Tong Haij yang menguasai tahun-tahun sebelum sebelum 1891. Penguasaan perdagangan opium di Keresidenan Kediri sesudah tahun 1891 dikuasai oleh Orang-orang Tionghoa yang berasal dari wilayah lain. Seperti Djie Thay Hien yang berasal dari wilayah Madiun. Perdagangan opium di Keresidenan Kediri dikuasai oleh orang-orang Tionghoa yang berasal dari luar tersebut disebabkan oleh bangkrutnya kongsi Kediri (perkumpulan orang-orang Tionghoa di Kediri) pada tahun 1890.

\section{Distribusi dan Penjualan}

Setelah pemenang lelang penjualan opium eceran ditetapkan dalam lelang opium, maka kewajiban dari pemerintah yakni menyediakan sejumlah opium mentah yang kemudian dikirim kepada pemenang lelang. Pemerintah menyediakan pasokan opium mentah di tiga gudang yang terletak di Batavia, Semarang dan Surabaya. Khusus untuk wilayah Jawa Timur mengambil pasokan opium mentah di Surabaya. Wilayah Keresidenan Kediri mengambil pasokan opium mentah yang berada di gudang pemerintah di Surabaya. Pasokan opium mentah yang didistribusikan disesuaikan dengan penandatanganan sebuah kontrak pasca lelang antara pihak pemerintah Hindia Belanda dengan pihak bandar beserta dua orang penjaminnya dalam lelang opium (James R.Rush, 2012: 50).

Pelaksanaan opiumpacht sebelum tahun 1860 dibawah naungan direktur sumber daya dan daerah (Directeur der Middelen en Domein). Setelah itu pelaksanaannya diganti dibawah direktur keuangan atau Directeur van Financien (Abdul Wahid, 2013: 60). Sejak saat ditangani oleh Directeur van Financien, perdagangan opium mengalami berbagai perubahan dalam kebijakan terutama mengenai distribusi opium mentah kepada para bandar.

Pada awal pelaksanaannya di Keresidenan Kediri yakni tahun 18331861, pemerintah memakai sistem minimum dengan penetapan siram dan jatah tiban. Distribusi dilakukan pada setiap satu bulan sekali. Berdasarkan temuan dari Javashe Courant wilayah Keresidenan Kediri pada tahun 1836 mendapatkan pasokan minimum sebesar 190 kati dalam satu bulan (Javasche Courant, 22 Oktober 1836). Artinya dalam setahun pemerintah memasok opium mentah ke wilayah Keresidenan Kediri mencapai 2.280 kati. Opium mentah yang dikirim terdiri atas opium Bengal mentah dan opium mentah Levant. Wilayah Keresidenan Kediri mendapatkan pasokan opium yang terdiri dari 50 opium Bengal (India) dan 135 opium Levant (Turki) dengan total keseluruhan mencapai 185 kati dalam sebulan pada tahun 1838 (Staatsblad 
van Nederlandsche-indie no. 65 tahun 1837).

Jumlah tersebut bisa naik juga bisa turun, semua tergantung dari banyaknya jumlah permintaan yang ada. Harga yang dijual oleh pemerintah yakni $f 100$ per kati yang terdiri dari opium Bengal India dan opium Levant Turki (Arsip Nasional Republik Indonesia, Soerat Peratoeran dari Beja Apioen di tanah Djawa dan Madura, (ANRI: Archieven Financien 1816-1930) no. 944: 5). Para opiumpachter diperbolehkan meminta opium mentah tambahan dari jumlah yang telah disediakan oleh pemerintah atau biasa disebut dengan siram. Harga opium siram lebih murah, hanya $f 35$ per kati. Opium siram tersebut biasanya diberikan kepada para onderpachter yang lebih kecil, warung-warung, tempat penjualan opium (tempat permadatan), atas izin dari penguasa atau hoofdpachter yang memenangkan hak penjualan opium pemerintah dalam lelang opium.

Distribusi opium untuk wilayah Keresidenan Kediri pada tahun 1851 mengalami peningkatan. Total jumlah distribusi pada tahun 1836 yang didapatkan sebanyak 190 kati menjadi sebanyak 290 kati per bulan pada tahun 1851. Jumlah tertinggi berada pada Distrik Kediri dengan penerimaan 60 kati, sedangkan untuk jumlah terendah terdapat pada Distrik Sukorejo dengan penerimaan sebanyak 20 kati. Untuk wilayah lain mendapatkan rata-rata 30 sampai 45 kati per bulan. Data tersebut mengidentifikasikan bahwa tiap-tiap distrik memiliki potensi yang sama besar dalam penggunaan opium untuk wilayah Keresidenan Kediri.

Tabel 3. Distribusi maksimum opium mentah di Keresidenan Kediri tahun 1862-1869

\begin{tabular}{ccc}
\hline Tahun & $\begin{array}{c}\text { Jumlah Keuntungan penjualan opium } \\
\text { mentah }(\boldsymbol{f} \text { 100) per tahun }\end{array}$ & $\begin{array}{c}\text { Jumlah maxima (kati) per } \\
\text { tahun }\end{array}$ \\
\hline 1862 & 654.000 & 6.450 \\
1863 & 564.000 & 6.450 \\
1864 & 564.000 & 6.450 \\
1865 & 564.000 & 6.450 \\
1866 & 564.000 & 6.450 \\
1867 & 564.000 & 6.450 \\
1868 & 562.000 & 5.626 \\
1869 & 563.800 & 5.638 \\
\hline
\end{tabular}

Sumber: Diolah dari Statistiek Betreffende de opiumpacht op Java en Madura over de jaren 1862-1866 dalam kolonial verslag tahun 1866; Statistik Betreffende de Opiumpacht op Java en Madura 1867-1869 dalam Kolonial Verslag tahun 1869.

Berdasarkan Tabel 3, pemerintah melakukan pergantian sistem distribusi minimum ke distribusi maksimum pada tahun 1862-1869. Hasil yang diperoleh sangat memuaskan dengan semakin meningkatnya penjualan opium mentah dan juga tingginya penawaran dalam lelang opium. Penjualan opium mentah pada tahun 1862 kepada bandar meningkat dua kalilipat dari 
tahun 1861 dengan persediaan tiban. Perolehan penjualan mentah pada tahun 1861 hanya sebesar 3.480 kati dalam setahun, sedangkan pada tahun 1862 menjadi 6.540 kati dalam setahun. Keuntungan yang diperoleh pemerintah dalam penjualan opium mentah di Keresidenan Kediri juga meningkat yakni dari tahun $f 348.000$ menjadi $f 654.000$ dalam setahun (Kolonial Verslag, 1866).

Pemerintah kembali menerapkan penjualan dengan distribusi minimum melalui tiban dan siram pada tahun 1870-1872. Kali ini intensitas jumlah opium tiban diperbesar menjadi duakalilipat dan mengurangi pasokan opium siram. Akibat dari kebijakan tersebut, pemerintah Hindia Belanda memperoleh keuntungan yang banyak dalam penjualan opium mentah (J.F. Scheltema, 1907: 93). Kebijakan tersebut tidak seimbang karena penawaran pacht pada lelang turun drastis.

Pemerintah Hindia Belanda pada tahun 1873 kembali menerapkan aturan jumlah maksimum distribusi opium. Secara perlahan pemerintah Hindia Belanda mulai meninggalkan sistem siram dan tiban dalam proses pendistribusian opium mentah kepada para bandar. Distribusi opium pada sistem tersebut dianggap kurang efektif dalam memuaskan permintaan bandar sehingga mereka beralih pada perdagangan opium ilegal. Oleh karena itu, pemerintah menggunakan kembali sistem maksimum yang diperkenalkan oleh Gubernur Jendral Loudon pada tahun 1862. Tujuan dibuat kebijakan distribusi maksimum adalah untuk memenuhi permintaan yang ada sehingga diharapkan dapat memerangi perdagangan ilegal yang sedang marak terjadi. Hasilnya jumlah permintaan opium mentah pada tahun 1873 di wilayah Keresidenan Kediri semakin meningkat dengan dibarengi oleh semakin bertambahnya jumlah tempat penjualan opium. Pemerintah Hindia Belanda memperoleh pendapatan yang besar dari penjualan opium di Wilayah Keresidenan Kediri (J.F. Scheltema, 1907: 94).

Pada tiap-tiap wilayah keresidenan ditentukan porsi maksimum pasokan opium mentah yang dikirim oleh pemerintah. Para bandar mendapatkan jumlah maksimum pasokan opium dari pemerintah yang terdiri opium mentah dari Levant Turki dan opium mentah dari Bengal India (Eric W. van Luijk and Jan C. van Ours, 2001: 5). Sejak saat itu, pemerintah juga menetapkan harga pembelian opium mentah dari pemerintah sebesar $f 30$ per kati. Selain itu, mereka juga menetapkan harga jual opium eceran kepada konsumen.

Sejak diberlakukan proses distribusi jatah maksimum oleh pemerintah Hindia Belanda, jatah maksimum wilayah Keresidenan Kediri dari beberapa tahun selalu mengalami peningkatan. Wilayah keresidenan Kediri pada tahun 1873-1874 menerima jumlah maksimum dari pemerintah Hindia Belanda sebanyak 9600 kati per tahun (Kolonial Verslag, 1875). Jumlah maksimum yang diterima pada tahun 1875 di wilayah Keresidenan Kediri meningkat 
menjadi 12.000 kati per tahun (Kolonial Verslag, 1875). Kondisi tersebut bertahan sampai pada akhir tahun 1880 .

Jumlah maksimum pada tahun 1881-1892 di Keresidenan Kediri kembali meningkat yakni menjadi 15.000 kati per tahun (Kolonial Verslag, 1882-1893). Pada tahun 1893 hingga berakhirnya masa pacht yakni tahun 1900 jatah maksimum yang dikirim oleh pemerintah total mencapai 18.000 kati per tahun (Kolonial Verslag, 1894-1901). Tingginya jatah maksimum yang diberikan oleh pemerintah disebabkan oleh banyaknya permintaan opium mentah yang dilakukan oleh para bandar di Keresidenan Kediri.

\section{Kemunduran}

Keuntungan yang besar menimbulkan resiko yang besar pula. Oleh karena itu, mereka diharuskan selalu waspada dan hati-hati dalam melakukan proses tawar menawar di lelang opium. Tawaran yang tinggi memikul beban yang besar dan bisa menyebabkan sebuah kehancuran dalam penjualan opium eceran. Para bandar opium bisa mendapatkan kesulitan-kesulitan yang dihadapi khususnya dalam melakukan pembayaran berupa prasarana (pachschat) atau pajak (pachtsom) dan harga penjualan opium mentah kepada pemerintah.

Beberapa kasus yang pernah menimpa bandar opium (opiumpachter) lokal adalah Tan Kok Tong. Ia memiliki hutang-hutang kepada negara yang begitu besar pada tahun 1887-1889. Hal tersebut diakibatkan oleh tingginya biaya pacht yang ditawarkan saat lelang berlangsung dan kondisi penjualan opium sedang tidak stabil. Selain itu, penjualan opium eceran yang dilakukan oleh bandar mendapatkan serangan-serangan dari pasar gelap sehingga penjualannyapun menjadi goyah. Hal tesebut terjadi karena pasar gelap menawarkan kualitas yang sama dan harga opium mentah yang lebih murah daripada opium mentah yang dijual oleh pemerintah.

Salah satu penyebab lain yang melatarbelakangi kemunduran dari pelaksanaan opiumpacht adalah kondisi perekonomian dari para bandar opium yang sedang dilanda masalah. Selain pada bidang perdagangan opium, mereka juga mengelola perkebunan kopi, pabrik gula dan perumahan-perumahan yang menjadi sebuah bisnis menguntungkan. Namun, keuntungan yang didapat bisa saja menjadi goyah. Ketika panen kopi turun, penjualan gula juga turun yang disebabkan oleh krisis yang terjadi maka kondisi keuangan para bandar menjadi tidak stabil. Tawaran kontrak yang tinggi pada saat lelang opium kepada pemerintah dan kondisi tersebut tidak bisa dibatalkan menjadi penyebab di antara bandar-bandar opium dan para kongsi (perkumpulan usaha) yang berkuasa di Jawa runtuh dalam sekejap. Mereka menderita hutang-hutang kepada negara karena tunggakan yang belum bisa dibayarkan pada setiap bulan. Seperti yang terlihat dalam peraturan opiumpacht, keterlambatan pembayaran maka pemerintah bisa mengenakan 
sanksi berupa denda sebesar $f 30$ apabila melewati tempo yang ditetapkan pemerintah (Staatsblad van Nederlandsche-indie no. 256, 1898).

Beberapa bandar yang memiliki hutang kepada negara dalam pelaksanaan opiumpacht di Keresidenan Kediri antara lain Tan Kok Tong dan Han Boen Kiet. Total hutang Tan Kok Tong secara keseluruhan dari tahun 1887 hingga tahun 1889 mencapai f 752.260 (Kolonial Verslag, 1890: 163). Total hutang Han Boen Kiet cs mencapai $f 221.310$ dengan rincian pachschat atau kewajiban prasarana sebesar $f 176.310$ dan penyediaan jatah maksimum sebesar $f 45.000$ tahun 1892-1894 (Arsip Nasional Republik Indonesia, Consideratien en advies van den Directeur van Financien 18 Augustus 1897 no. 17502 (ANRI: Algemene Secretarie Grote Bundel M.G.S 1890-1942 no 3926).

\section{Kesimpulan}

Monopoli perdagangan opium atau lebih dikenal dengan opiumpacht di Keresidenan Kediri terjadi pada kurun tahun 1833-1900. Proses monopoli dilakukan dengan menunjuk perantara bandar sebagai mitra dalam penjualan opium eceran ditentukan melalui lelang berdasarkan penawaran tertinggi. Perantara bandar opium di Keresidenan Kediri hampir secara keseluruhan selalu dimenangkan oleh orang-orang Tionghoa. Mereka selalu unggul dari sisi strategi dan ekonomi sehingga bisa memberikan tawaran yang tinggi kepada pemerintah. Beberapa bandar opium Tionghoa di Keresidenan Kediri yaitu Tan Kok Tong, Kwee Swie Toan, Tan Hwat Hien, dan Tan Tong Haij, Han Boen Kiet, Djie Thay Hien.

Pada awal pelaksanaanya pemerintah menerapkan distribusi minimum penetapan jatah tiban dan jatah siram. Hasil yang diperoleh tidak begitu maksimal karena penawaran yang diberikan mengalami naik turun. Pemerintah kemudian mengganti distribusi minimum ke distribusi maksimum pada tahun 1873. Sejak saat itu, pendapatan yang diperoleh melalui pajak opium di Keresidenan Kediri mengalami kenaikan hingga duakalilipat dari tahun-tahun sebelumnya. Pemerintah selalu diuntungkan dengan adanya penawaran yang tinggi. Kondisi tersebut sedikit berbeda dengan yang dialami bandar opium. Tingginya pajak yang diberikan bisa membuat mereka mengalami kesulitan-kesulitan yang besar. Oleh karena itu, mereka sebisa mungkin menekan penawaran yang tinggi saat lelang berlangsung.

Kemunduran pelaksanaan opiumpacht terjadi pada akhir abad ke-19 yang diakibatkan oleh adanya krisis sehingga penjualan opium eceran tidak selalu memperoleh hasil yang baik. Kondisi tersebut diperparah oleh tingginya tawaran yang diberikan sehingga banyak di antara bandar opium menunggak pembayaran pajak bulanan kepada pemerintah. Beberapa bandar opium di Keresidenan Kediri yang memiliki hutang kepada pemerintah yaitu Tan 
Kok Tong pada periode tahun 1887-1889 dan Han Boen Kiet pada periode penjualan opium tahun 1892-1894. Krisis menyebabkan kongsi-kongsi besar di Jawa runtuh dalam sekejap. Salah satunya kongsi Kediri (perkumpulan orang-orang Tionghoa di Kediri). Sejak keruntuhan kongsi Kediri, persaingan antar bandar semakin menurun dengan minimnya calon bandar opium lokal yang bersedia ikut dalam lelang. Pemerintah mulai mengganti secara bertahap pelaksanaan opiumpacht ke opiumregie. Hal tersebut menjadi penanda berakhirnya monopoli perdagangan opium melalui perantara bandar dengan digantikan oleh para pegawai mantri penjualan opium yang digaji langsung pemerintah.

\section{Daftar Pustaka}

\section{Sumber Primer}

Arsip Nasional Republik Indonesia. Consideratien en advies van den Directeur van Financien 18 Augustus 1897 no. 17502 (ANRI: Algemene Secretarie Grote Bundel M.G.S 1890-1942 no. 3926).

Arsip Nasional Republik Indonesia. Rapport van 10 November 1894 (ANRI: Algemene Secretary Serie Grote Bundel Missive Gouvernements Secretary 1890-1942, 1890 no. 3926).

Arsip Nasional Republik Indonesia. Rapport van 11 November 1890 (ANRI: Algemene Secretary Serie Grote Bundel Missive Gouvernements Secretary 1890-1942, 1890 no. 3746).

Arsip Nasional Republik Indonesia. Soerat Peratoeran dari Beja Apioen di tanah Djawa dan Madura (ANRI: Archieven Financien 1816-1930) no. 944: 5).

Arsip Nasional Republik Indonesia. Verpachting van het regt tot den verkoop van opium in het klein (ANRI: Archieve van Financien 1816-1930 no. 944).

De Locomotief: Handels-en advertientie blad, 10 Agustus 1875.

Javasche Courant, 22 Oktober 1836.

Koloniaal Verslag tahun 1866.

Koloniaal Verslag tahun 1869.

Koloniaal Verslag tahun 1871-1901.

Soerabaiasch-Handelsblad, 1886.

Staatsblad van Nederlandsche-indie no. 256 tahun 1898.

Staatsblad van Nederlandsche-indie no. 65 tahun 1837.

\section{Buku dan Sumber Cetakan}

Ibrahim, Julianto. OPIUM DAN REVOLUSI Perdagangan dan Penggunaan Opium di Surakarta Masa revolusi (1945-1950). Yogyakarta: Pustaka Pelajar, 2013.

Kuntowijoyo. Pengantar Ilmu Sejarah. Yogyakarta: Tiara Wacana, 2013.

Nurdin, Adnil Edwin. Madat, Sejarah, Dampak Klinis dan Penanggulangannya. Semarang: Mutiara Wacana, 2007.

Rush, James R. Candu Tempo Doeloe Pemerintah, Pengedar dan Peopium 1860-1910. Jakarta: Komunitas Bambu, 2012.

Salmon, Claudine Lombard. "The Han Family of East Java. Entrepreneurship and Politics (18 ${ }^{\text {th }}-19^{\text {th }}$ Centuries)", dalam Archipel, Volume 41, 1991: 77-79.

Sartono Kartodirdjo, Marwati Djoened Poesponegoro, dkk. Sejarah Nasional Indonesia IV. Jakarta: Balai Pustaka, 1977. 
Scheltema, J.F. "The Opium Trade in the Ducht East Indies.1," American Journal of Sociology, vol 13, no.1, pp 79-112. The University of Chicago Press, 1907.

Van Ours, Eric W. van Luijk and Jan C. "The Effect of Government Policy on Drug Use: Java, 1832-1904", Journal of Economic History, vol.61, No.1 pp, 1-18, (Cambridge University), 2001.

Vleming Jr., J.L. Kongsi \& Spekulasi Jaringan Kerja Bisnis Cina. Jakarta: Pustaka Utama Graffiti, 1989.

Baud and Hoffman, J.C. Proeve van Eene Geschiedenis van Handel en Het Verbruik van Opium in Nederlandsche Indie. Leiden: Brill, 1853.

Wahid, Abdul. From Revenue Farming to state Monopoly: The political Economy of Taxation in Colonial Indonesia, Java c. 1816-1942. Belanda: Utrecht University, 2013. 